\title{
Relative growth and reproduction in Achelous spinicarpus (Crustacea: Portunidae) on the south-eastern continental shelf of Brazil
}

\author{
ANDRÉ L. PARDAL-SOUZA AND MARCELO A.A. PINHEIRO \\ UNESP-Univ. Estadual Paulista, Campus Experimental do Litoral Paulista (CLP), Grupo de Pesquisa em Biologia de Crustáceos \\ (CRUSTA), Laboratório de Biologia de Crustáceos, Praça Infante Dom Henrique, s/nº, CEP 11330-90o, São Vicente, São Paulo, \\ Brazil
}

\begin{abstract}
This investigation aimed to study the relative growth, morphological sexual maturity and fecundity of the swimming crab Achelous spinicarpus in a tropical region, on the south-eastern continental shelf of Brazil $\left(25^{\circ} \mathrm{S}\right)$. Biometry of all specimens was conducted, including measurements of the cephalothorax, cheliped, abdomen and gonopods. Relative growth was described based on the equation for allometry $\left(y=a x^{b}\right)$, and size at sexual maturity was determined from inflections in relations involving the cheliped, gonopods (males), and abdomen (females), as dependent variables, related to the cephalothorax width (independent variable). Fecundity was estimated by the gravimetric method. The relations of the length of the chelar propodus and carpal spine to the carapace width without the lateral spines $(C W)$ showed positive allometry in both sexes, with a significant variation in the constant ' $b$ ' for males between the developmental stages (juvenile and adult) and the size at maturity estimated at $37 \mathrm{~mm} \mathrm{CW}$. In females, the abdomen was most appropriate for the estimate of morphological maturity, which occurred at a smaller size $(32 \mathrm{~mm} \mathrm{CW})$, with a change in the growth pattern between the stages, passing from isometric (juveniles) to positive allometric (adults). The gonopods also showed different growth rates between developmental stages, in synchrony with the variables of the cheliped. Mean fecundity for the species was 53,984 eggs, with a positive correlation between the number of eggs exteriorized and the size of the female; the equations allowed interconversion between these variables, due to the adjustment of the power function $\left(r^{2} \geq 86 \%\right)$.
\end{abstract}

Keywords: Brachyura, fecundity, morphological maturity, swimming crab

Submitted 4 February 2012; accepted 17 February 2012; first published online 28 March 2012

\section{INTRDDUCTION}

Portunid crabs are ecologically prominent as important elements of trophic webs of the marine and estuarine benthos, and have great influence on the dynamics and structuring of these environments (Pires, 1992; Braga et al., 2005). In addition, they constitute a group with economic importance for the extraction of their meat and by-products derived from their industrial processing (Haefner, 1985; Pinheiro \& Fransozo, 2002; Hattori et al., 2006; Rasheed \& Mustaquim, 2010), activities that have been conducted successfully in different countries since the 1990s (FAOGLOBEFISH, 2007).

Achelous spinicarpus Stimpson, 1871 is a species with a wide geographical distribution, from North Carolina, USA to Rio Grande do Sul, Brazil (Melo, 1996), and it occurs from shallow waters to $550 \mathrm{~m}$ depth (Williams, 1984). Although several investigators have described the great abundance of this portunid in the western Atlantic (García-Montes et al., 1988; Sartor, 1989;

Corresponding author:

M.A.A. Pinheiro

Email: pinheiro@clp.unesp.br
Puentes et al., 1990; Bertini \& Fransozo, 2004; Braga et al., 2005), as well as its association with the South Atlantic Central Water (SACW) (Pires, 1992; De Léo \& Pires-Vanin, 2006), little is known about its biology, ecology, or morphological aspects. The few studies on this species include the description by Holthuis (1969); its distinction by means of molecular biology from another congeneric species, Achelous binoculus (Holthuis, 1969), carried out by Mantelatto et al. (2007); the complete description of its larval stages by Bookhout \& Costlow (1974); the analysis of its morphometry and relative growth by Sanvicente-Anõrve et al. (2008); and the study by Mantelatto et al. (2009), who proposed the re-elevation of the genus Achelous De Haan, 1833 for the American species formerly assigned to the genus Portunus Weber, 1725, based on molecular phylogeny. In addition, this swimming crab figures in the by-catch of fisheries for the lobster Metanephrops rubellus (Moreira, 1903) and marine shrimps (Severino-Rodrigues et al., 2002, 2007), which has a negative impact on its populations as a result of this inadequate management.

The objective of this study was to describe the relative growth and to determine the size at maturity through morphological analysis of each sex of A. spinicarpus, as well as to estimate the potential fecundity of this species off the southeastern Brazilian coast. 


\section{MATERIALS AND METHDDS}

The specimens were collected in December 2007 on the southeastern continental shelf, using the RV 'Soloncy Moura', outfitted with an otter-trawl net (mesh size $20 \mathrm{~mm}$ knot-to-knot). The sampling consisted of a single bottom trawl over a distance of $2.6 \mathrm{~km}$ ( 1.4 nautical miles), beginning at the coordinates $25^{\circ} 50^{\prime} 31.14^{\prime \prime} \mathrm{S} / 46^{\circ} 58^{\prime} 25.16^{\prime \prime} \mathrm{W}$ and ending at $25^{\circ} 49^{\prime} 24.12^{\prime \prime} \mathrm{S} /$ $46^{\circ} 57^{\prime} 30.12^{\prime \prime} \mathrm{W}$, at depths ranging from 95 to $100 \mathrm{~m}$.

After they were caught, the specimens of $A$. spinicarpus were sorted from the other organisms and kept cold until the analyses. Each specimen had its sex determined based on the abdominal dimorphism and number of pleopods (as recommended by Pinheiro \& Fransozo, 1998), and was also measured with a digital caliper $(0.01 \mathrm{~mm})$ and, when necessary, an image-analysis system. The morphological structures analysed were: cephalothorax (CW, width excluding lateral spines; CWS, width including lateral spines; and CL, length); major cheliped (PL, propodus length; CS, carpal spine length; PW, propodus width; and $\mathrm{PH}$, propodus height); abdomen (AW5, greatest width of the 5th abdominal somite; and AW6, greatest width of the 6th abdominal somite); and gonopods (GL1, length of the 1st pair; and GL2, length of the 2nd pair). Each of the biometric variables was evaluated with respect to its values (minimum, maximum, mean and standard deviation), comparing the means between the sexes by the Student's $t$-test $(\alpha=0.05)$ (Zar, 1996).

\section{Relative growth and morphological maturity}

All biometric relations were submitted to regression analysis, with an adjustment by the power function $\left(y=a x^{b}\right)$ (Huxley, 1950), using CW as the independent variable $(x)$ and the others as dependent variables $(y)$. For the determination of the stages of development the segmented ('broken-line') linear model $(\ln y=\ln a+b \ln x)$ was used, by means of the 'segmented' library (Muggeo, 2008), available in the ' $\mathrm{R}$ Version 2.13.0' environment ( $\mathrm{R}$ Development Core Team, 2011), because there was no evident morphological dimorphism between the developmental stages (juvenile and adult) for both sexes in this species. The allometric growth rate of each stage was determined based on the value of the constant ' $b$ ', so that $b=1$ indicates isometric growth, $\mathrm{b}>1$ positive allometric and $\mathrm{b}<1$ negative allometric; the difference of the unit was evaluated by the Student's $t$-test $(\alpha=0.05)$. Morphological sexual maturity was determined based on the relations involving the cheliped and gonopods in males $(\mathrm{PL} \times \mathrm{CW}, \mathrm{CS} \times \mathrm{CW}, \mathrm{GL} 1 \times \mathrm{CW}$ and $\mathrm{GL} 2 \times$ $\mathrm{CW})$ and the abdomen in females (AW $5 \times \mathrm{CW}$ and AW6 $\times$ $\mathrm{CW}$ ), considering the inflection point indicated by the segmentation of the log-transformed mathematical model.

\section{Fecundity}

Fecundity is defined as the number of eggs exteriorized by a female in each spawning (Sastry, 1983). For the study of this parameter, only females with eggs in the initial stage of embryonic development (end of the blastula and beginning of the gastrula), according to the classification of Boolootian et al. (1959), were included; this minimizes errors stemming from the lack of fertilization or loss of eggs in the later stages (Pinheiro \& Terceiro, 2000). The pleopods of each female were removed with scissors. The egg mass was dehydrated in $70 \%$ ethanol ( 24 hours), followed by pure ethanol (12 hours); and later dried in an oven $\left(60^{\circ} \mathrm{C}\right)$ until constant weight, recorded on an analytic balance ( $0.0001 \mathrm{~g})$. From each egg mass, three subsamples ( $2 \mathrm{mg}$ each) were separated; the number of eggs was counted under a stereomicroscope, with a manual mechanical counter; next, the total number of eggs in the egg mass (NE) estimated by the simple rule of three based on the mean of the subsamples, was calculated. The coefficient of variation was determined for each egg mass; values above $10 \%$, caused by methodological error (dehydration and/or counting), were discarded, and the discrepant subsample was replaced by another, in order to reduce this statistical parameter in accordance with the procedure suggested by Pinheiro \& Terceiro (2000).

The dependent variable (NE) was related to the independent variables representative of body size (CW and CWS); the empirical points of these relations $(\mathrm{NE} \times \mathrm{CW}$ and $\mathrm{NE} \times$ CWS) were submitted to regression analysis, adjusted by the power function.

\section{RESULTS}

\section{Relative growth and morphological maturity}

A total of 265 individuals of A. spinicarpus were analysed, 146 males and 119 females (6o ovigerous and 59 non-ovigerous). The descriptive statistics for the biometric variables are presented in Table 1 . With the exception of the abdominal somites (AW 5 and AW6), which were larger in females $(t=$ 25.1 and $t=25.5$, respectively; $P<0.05)$, as well as $\mathrm{PW}$, which showed no statistical difference $(t=1.09 ; P>0.05)$, the remaining structures (CW, CWS, CL, PL, CS and PH) were significantly larger in males $(t=2.9, t=3.3, t=2.02$, $t=9.7, t=20.4$ and $t=5.3$, respectively; $P<0.05)$.

The CL $\times$ CW relation was isometric in both sexes $(\mathrm{b}=$ 1.01; males: $t=0.807$; females: $t=1.50 ; P>0.05)$, allowing it to be represented by a single equation $\left(\mathrm{CL}=0.603 \mathrm{CW}^{1.01}\right.$, $\left.\mathrm{N}=264, \mathrm{r}^{2}=0.98\right)$. For CWS $\times \mathrm{CW}$, a decrease in the growth rate was noted between the developmental stages of males (positive to negative allometric) and females (isometric to negative allometric) (Table 2), with the break-points estimated at 37.3 and $36.6 \mathrm{~mm}$, respectively.

For both sexes, the relations involving the cheliped showed positive allometry, with the exception of PW (Table 2). In males, the greatest variations of the constant ' $b$ ' between the developmental stages were observed for the relations CS $\times$ $\mathrm{CW}$ and $\mathrm{PL} \times \mathrm{CW}$, with morphological maturity estimated at 36.9 and $37.1 \mathrm{~mm}$, respectively (Figure 1). In females, on the other hand, no inflection was found in the trend of the empirical points for these regressions. The inverse was observed for the abdomen of females, independently of the relation evaluated $\left(\mathrm{AW}_{5} \times \mathrm{CW}\right.$ and AW6 $\left.\times \mathrm{CW}\right)$, with a significant positive allometry in the adult stage; whereas in males, no alteration was detected in the growth rate between the juvenile and adult stages for these relations. Females matured at a smaller size than males: 31.1 (AW5) and $32 \mathrm{~mm}$ (AW6) (Figure 2).

The relations of the gonopods showed an inflection point synchronous with that observed for the relations of the cheliped, i.e. $35.5 \mathrm{~mm}$ for $\mathrm{GL} 1 \times \mathrm{CW}$ and $36.9 \mathrm{~mm}$ for $\mathrm{GL} 2 \times$ $\mathrm{CW}$. For GL1 $\times \mathrm{CW}$ there was a change in the growth rate between the developmental stages (isometric to negative allometric); whereas for $\mathrm{GL} 2 \times \mathrm{CW}$, growth was isometric, although the difference between the constant ' $b$ ' of the juvenile and adult stages was not statistically significant (Table 2). 
Table 1. Achelous spinicarpus Stimpson, 1871: descriptive statistics of the biometric variables evaluated for both sexes (CW, carapace width without lateral spines; CWS, carapace width with lateral spines; CL, carapace length; PL, propodus length; CS, carpal spine length; PW, propodus width; PH, propodus height; AW 5 , width of the 5th abdominal somite; AW6, width of the 6th abdominal somite; GL1, length of the 1st gonopod pair; GL2, length of the 2 nd gonopod pair)

\begin{tabular}{|c|c|c|c|c|c|c|c|c|}
\hline \multirow{3}{*}{ Variables } & \multicolumn{8}{|c|}{ Values (mm) } \\
\hline & \multicolumn{4}{|c|}{ Males } & \multicolumn{4}{|c|}{ Females } \\
\hline & $\mathbf{N}$ & Min & Mean \pm SD & $\operatorname{Max}$ & $\mathbf{N}$ & Min & Mean $\pm S D$ & $\operatorname{Max}$ \\
\hline CW & 146 & 27.43 & $37.60 \pm 3.70$ & 47.44 & 119 & 27.50 & $36.05 \pm 4.96$ & 48.20 \\
\hline CWS & 136 & 39.19 & $53.78 \pm 4.98$ & 66.47 & 119 & 40.04 & $51.35 \pm 6.54$ & 63.35 \\
\hline $\mathrm{CL}$ & 146 & 16.41 & $23.13 \pm 2.32$ & 29.80 & 118 & 17.05 & $22.43 \pm 3.16$ & 29.95 \\
\hline PL & 146 & 21.67 & $34.09 \pm 5.11$ & 47.44 & 114 & 20.58 & $28.45 \pm 4.19$ & 37.42 \\
\hline CS & 140 & 12.01 & $22.79 \pm 5.22$ & 39.51 & 112 & 8.45 & $12.65 \pm 2.38$ & 18.82 \\
\hline PW & 141 & 2.56 & $3.36 \pm 0.33$ & 4.60 & 113 & 2.51 & $3.42 \pm 0.47$ & 4.91 \\
\hline PH & 144 & 4.51 & $6.45 \pm 0.76$ & 8.40 & 111 & 4.29 & $5.91 \pm 0.87$ & 8.37 \\
\hline $\mathrm{AW}_{5}$ & 145 & 5.03 & $7.50 \pm 0.91$ & 9.87 & 117 & 10.00 & $14.14 \pm 2.73$ & 20.70 \\
\hline AW6 & 145 & 3.68 & $5.54 \pm 0.65$ & 7.27 & 116 & 7.68 & $11.56 \pm 2.48$ & 17.44 \\
\hline $\mathrm{GL}_{1}$ & 145 & 4.63 & $6.48 \pm 0.63$ & 8.40 & - & - & - & - \\
\hline GL2 & 143 & 2.22 & $3.44 \pm 0.43$ & 4.59 & - & - & - & - \\
\hline
\end{tabular}

$\mathrm{N}$, number of specimens; Min, minimum; Max, maximum; SD, standard deviation.

\section{Fecundity}

A total of 60 ovigerous females were analysed, with CW ranging between 27.5 and $48.2 \mathrm{~mm}(36.03 \pm 5.72 \mathrm{~mm})$ and CWS between 40.1 and $64.8 \mathrm{~mm} \quad(51.18 \pm 7.3 \mathrm{~mm})$. Potential fecundity was estimated at between 14,745 and
132,392 eggs (53,984 $\pm 27,658$ eggs). Significant positive correlations were observed for the relations $\mathrm{NE} \times \mathrm{CW}$ and $\mathrm{NE} \times$ CWS $(r=0.93, F=411.93$; and $r=0.92, F=231.21$, respectively; $P<0.0001$ ), which show a curvilinear trend, expressed by the power functions $\mathrm{NE}=0.422 \mathrm{CW}^{3.25} \quad\left(\mathrm{r}^{2}=0.89\right)$ (Figure 3) and $\mathrm{NE}=0.0416 \mathrm{CWS}^{3.55}\left(\mathrm{r}^{2}=0.86\right)$.

Table 2. Achelous spinicarpus Stimpson, 1871: regression analyses of biometric variables of the cephalothorax (CL, carapace length; CWS, carapace width with lateral spines), cheliped (PL, propodus length; CS, carpal spine length; PH, propodus height; PW, propodus width), abdomen (AW5, width of the 5th abdominal somite; AW6, width of the 6th abdominal somite), and gonopods (GL1, length of the 1st gonopod pair; GL2, length of the 2nd gonopod pair), related to the independent variable (CW, carapace width without lateral spines).

\begin{tabular}{|c|c|c|c|c|c|c|}
\hline Variable & Sex/stage & $\mathbf{N}$ & Power function & $\mathbf{r}^{2}$ & $t^{*}$ & Allometry $(P<0.05)$ \\
\hline CL & Total & 264 & $\mathrm{CL}=0.603 \mathrm{CW}^{1.01}$ & 0.98 & 0.78 & 0 \\
\hline \multirow[t]{4}{*}{ CWS } & $\mathrm{JM}$ & 77 & $\mathrm{CWS}=0.98 \mathrm{CW}^{1.10}$ & 0.86 & 2.14 & + \\
\hline & $\mathrm{AM}$ & 56 & $\mathrm{CWS}=2.806 \mathrm{CW}^{0.81}$ & 0.90 & 5.14 & - \\
\hline & $\mathrm{JF}$ & 68 & $\mathrm{CWS}=1.501 \mathrm{CW}^{0.98}$ & 0.92 & 0.36 & o \\
\hline & $\mathrm{AF}$ & 51 & $\mathrm{CWS}=2.73 \mathrm{CW}^{0.82}$ & 0.83 & 3.50 & - \\
\hline \multirow[t]{3}{*}{ PL } & JM & 80 & $\mathrm{PL}=0.57 \mathrm{CW}^{1.41}$ & 0.87 & 5.89 & + \\
\hline & $\mathrm{AM}$ & 64 & $\mathrm{PL}=0.47 \mathrm{CW}^{1.56}$ & 0.88 & 7.70 & + \\
\hline & $\mathrm{TF}$ & 114 & $\mathrm{PL}=0.59 \mathrm{CW}^{1.07}$ & 0.96 & 4.19 & + \\
\hline \multirow[t]{3}{*}{ CS } & $\mathrm{JM}$ & 72 & $\mathrm{CS}=0.041 \mathrm{CW}^{1.72}$ & 0.69 & 5.36 & + \\
\hline & $\mathrm{AM}$ & 68 & $\mathrm{CS}=0.0055 \mathrm{CW}^{2.28}$ & 0.79 & 9.04 & + \\
\hline & $\mathrm{TF}$ & 112 & $\mathrm{CS}=0.103 \mathrm{CW}^{1.34}$ & 0.89 & 7.89 & + \\
\hline \multirow[t]{2}{*}{ PH } & $\mathrm{TM}$ & 144 & $\mathrm{PH}=0.093 \mathrm{CW}^{1.16}$ & 0.93 & 6.42 & + \\
\hline & $\mathrm{TF}$ & 111 & $\mathrm{PH}=0.13 \mathrm{CW}^{1.06}$ & 0.94 & 2.72 & + \\
\hline \multirow[t]{2}{*}{ PW } & $\mathrm{TM}$ & 141 & $\mathrm{PW}=0.12 \mathrm{CW}^{0.91}$ & 0.83 & 2.53 & o \\
\hline & $\mathrm{TF}$ & 113 & $\mathrm{PW}=0.11 \mathrm{CW}^{0.96}$ & 0.87 & 1.22 & o \\
\hline \multirow[t]{3}{*}{$\mathrm{AW}_{5}$} & $\mathrm{TM}$ & 144 & $\mathrm{AW}_{5}=0.13 \mathrm{CW}^{1.10}$ & 0.79 & 2.19 & + \\
\hline & JF & 23 & $\mathrm{AW}_{5}=0.25 \mathrm{CW}^{1.10}$ & 0.41 & 0.37 & o \\
\hline & $\mathrm{AF}$ & 92 & $\mathrm{AW}_{5}=0.097 \mathrm{CW}^{1.38}$ & 0.93 & 9.96 & + \\
\hline \multirow[t]{3}{*}{ AW6 } & $\mathrm{TM}$ & 142 & $\mathrm{AW} 6=0.097 \mathrm{CW}^{1.11}$ & 0.89 & 3.52 & + \\
\hline & JF & 24 & $\mathrm{AW} 6=0.075 \mathrm{CW}^{1.39}$ & 0.55 & 1.46 & o \\
\hline & $\mathrm{AF}$ & 92 & $\mathrm{AW} 6=0.044 \mathrm{CW}^{1.54}$ & 0.92 & 11.59 & + \\
\hline \multirow[t]{2}{*}{ GL1 } & $\mathrm{JM}$ & 50 & $\mathrm{GL}_{1}=0.12 \mathrm{CW}^{1.09}$ & 0.79 & 1.17 & o \\
\hline & $\mathrm{AM}$ & 92 & $\mathrm{GL} 1=0.25 \mathrm{CW}^{0.88}$ & 0.82 & 2.56 & - \\
\hline \multirow[t]{2}{*}{ GL2 } & JM & 73 & $\mathrm{GL}_{2}=0.042 \mathrm{CW}^{1.21}$ & 0.63 & 1.94 & o \\
\hline & $\mathrm{AM}$ & 67 & $\mathrm{GL}_{2}=0.059 \mathrm{CW}^{1.12}$ & 0.78 & 1.68 & o \\
\hline
\end{tabular}

${ }^{*} t$-test, $\mathrm{H}_{\mathrm{o}}: \mathrm{b}=1$, isometry; Total, males plus females; JM, juvenile males; AM, adult males; TM, total males; JF, juvenile females; AF, adult females; TF, total females; o, isometry; + , positive allometry; - , negative allometry. 

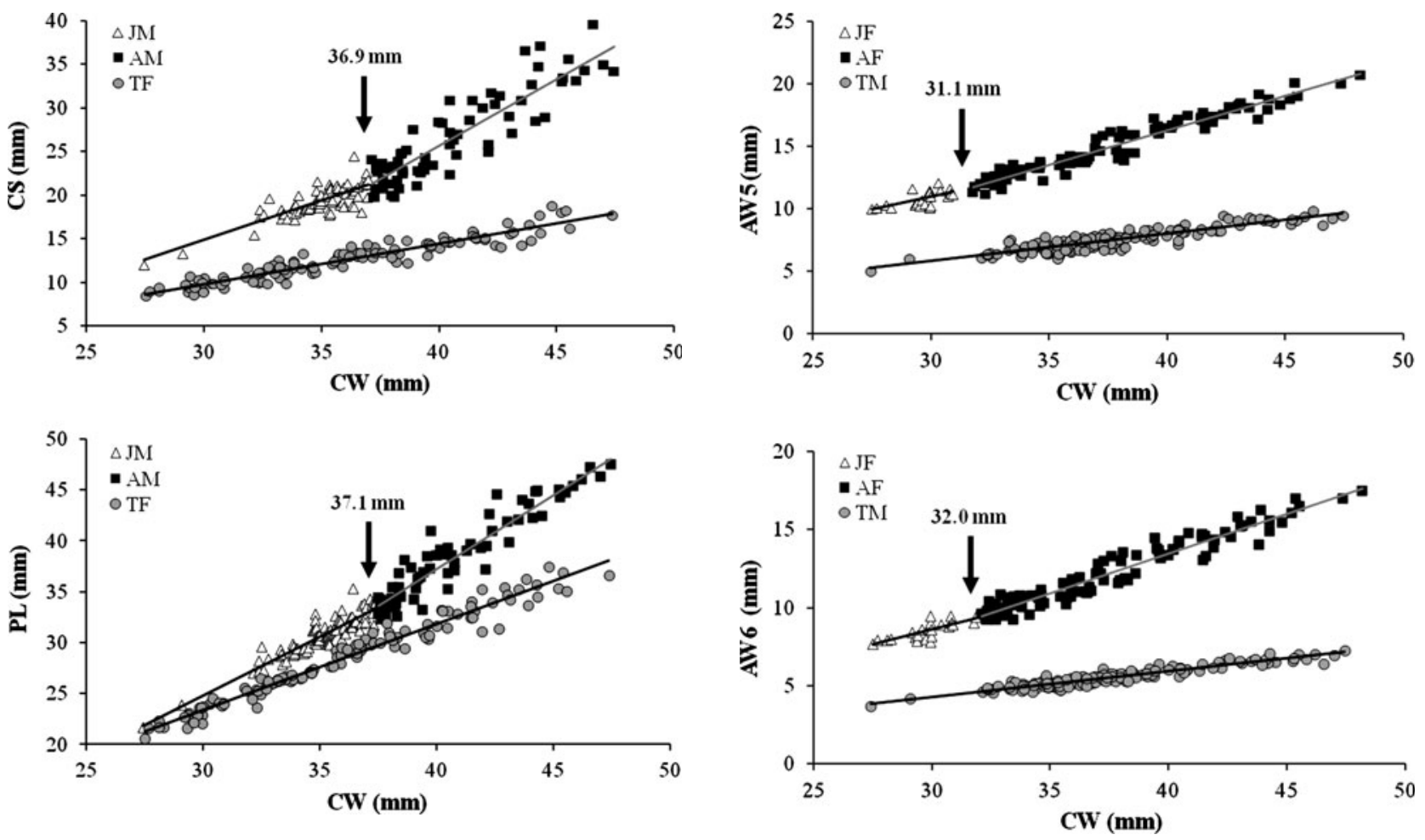

Fig. 1. Achelous spinicarpus Stimpson, 1871: graph of dispersion of points of the biometric relationships $\mathrm{CS} \times \mathrm{CW}$ and $\mathrm{PL} \times \mathrm{CW}$, for both sexes, with indication of the size at morphological maturity (arrow). CS, carpal spine length; PL, propodus length; CW, carapace width without lateral spines; JM, juvenile males; AM, adult males; TF, total females.

\section{DISCUSSIDN}

\section{Relative growth and morphological maturity}

The present study provided important information on the morphology, growth and reproduction of Achelous spinicarpus for the south-eastern continental shelf of Brazil, which adds to the sparse available information on this common and abundant species in the western Atlantic.

Although the smallest specimen collected was a male (CW $=27.43 \mathrm{~mm})$ and the largest was a female $(\mathrm{CW}=48.2 \mathrm{~mm})$, the males were significantly larger, as also observed by Sanvicente-Añorve et al. (2008). The larger body size reached by males is common in portunids, and is a result of the differential allocation of energy to somatic growth in this sex, in contrast to the females, which have a large part of their energy directed toward gonadal maturation and egg production (Hartnoll, 1985). This difference is a reproductively advantageous adaptation during the formation of pairs, a common feature of portunids, in which the larger males provide protection to the females in post-moult (Christy, 1987), when they are in copula, until their exoskeleton calcifies (Hartnoll, 1969).

The variation in size (CW) of $A$. spinicarpus found in this study was similar to that observed by other investigators, such as Holthuis (1969), who evaluated several populations of this species from the Florida Strait (USA) $\left(25^{\circ} \mathrm{N}\right)$ to French Guiana $\left(5^{\circ} \mathrm{N}\right)$; and Sanvicente-Añorve et al. (2008) for a population in the south-eastern Gulf of Mexico $\left(22^{\circ} \mathrm{N}\right)$. The greater difference of the present data from the second study probably results from sampling selectivity by the trawl net $(20 \mathrm{~mm}$

Fig. 2. Achelous spinicarpus Stimpson, 1871: graph of dispersion of points of the biometric relationships AW $5 \times \mathrm{CW}$ and AW6 $\times \mathrm{CW}$, for both sexes, with indication of the size at morphological maturity (arrow). AW 5 , width of 5 th abdominal somite; AW6, width of 6th abdominal somite; CW, carapace width without lateral spines; TM, total males; JF, juvenile females; AF, adult females.

knot-to-knot). In addition, Holthuis (1969) mentioned that the juvenile of this species occur at depths less than $86 \mathrm{~m}$, which would explain the absence of individuals with $\mathrm{CW}<$ $27 \mathrm{~mm}$ in the present study (95 and $100 \mathrm{~m}$ ) and their recording by Sanvicente-Añorve et al. (2008), at depths of $60 \mathrm{~m}$. In spite of these differences, the size distribution of A. spinicarpus in the present study appears to be representative, because the sample obtained at the $100-\mathrm{m}$ isobath was very similar to that recorded by Holthuis (1969), although his sampling has been more comprehensive with regard to depth (14 to $406 \mathrm{~m}$ ) as well as geographical distribution.

In male brachyurans, the greater development of the chelipeds is considered a secondary sexual character, related to the

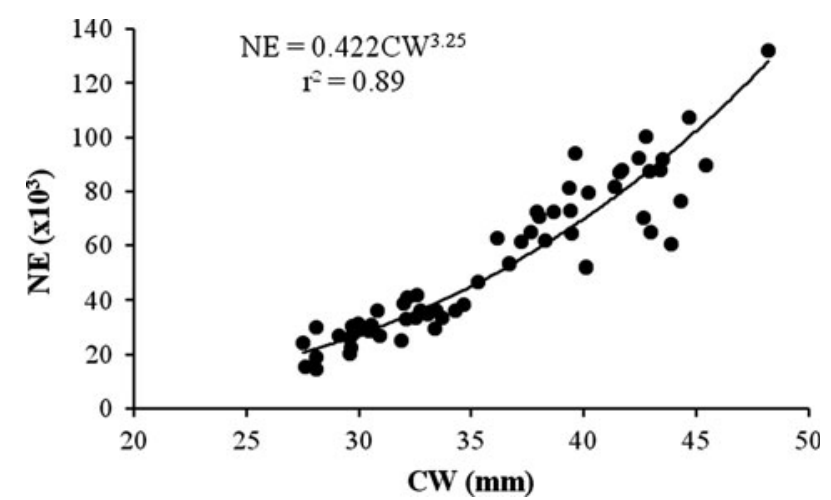

Fig. 3. Achelous spinicarpus Stimpson, 1871: relationship between the number of eggs (NE) and the biometric parameter of the cephalothorax (CW, carapace width without lateral spines). 
display of agonistic behaviours (e.g. combats for females and territorial defence) and reproductive behaviours (e.g. courtship and maintenance of copulation), according to studies by Hartnoll $(1974,1978)$ and Jivoff \& Hines (1998). In females, on the other hand, the widening of the abdomen and opening of the gonopores in the puberty moult are morphological aspects of extreme importance for the success of copulation, providing protection for the egg mass and the genital openings (Pinheiro \& Fransozo, 1998). For A. spinicarpus, the same pattern was observed with respect to the differential allometry of these appendices in each sex.

The carpal spines of the cheliped proved to be an excellent feature for use in the detection of dimorphism between the sexes (as previously suggested by Sanvicente-Añorve et al., 2008), as well as the size at morphological maturity of the males; the carpal spines were more important than the length of the propodus, a structure that is widely used in this type of study. Similarly, as observed for other species (e.g. Hartnoll, 1965; Flores \& Negreiros-Fransozo, 1999; Pinheiro \& Hattori, 2006; Freire et al., 2011), the gonopods provided a reliable estimate of this parameter, in synchrony with other body structures, because of their importance in transferring the spermatophores.

In the available literature on portunids, there is no consensus as to which biometric variable is more representative of the cephalothorax (CW or CWS), or which of these should be used as a reference size. Although the majority of investigators use CW, a few use CWS in biometrics, making comparison difficult because it requires a conversion between these variables. In the present study, the relation CWS $\times \mathrm{CW}$ showed a decrease in the growth rate between the developmental stages for both sexes, in synchrony with the other body structures that are traditionally used in analyses of morphological maturity for males $( \pm 37 \mathrm{~mm})$. This signifies that the lateral spines grow proportionately more in juveniles; this possibly represents an anti-predator adaptation, as in the dorsal and rostral spines of the zoeas (Morgan, 1987). For the swimming crabs Arenaeus cribrarius (Lamarck, 1818) and Callinectes ornatus Ordway, 1863, studied by Haefner (1990) and Pinheiro \& Fransozo (1993), respectively, this pattern was not observed, the relation being typically isometric. This regression has been examined in few publications; nevertheless, the result obtained here assures that it will be important in future studies of relative growth, at least in species of Portunidae.

The size at which crustaceans become sexually mature is one of the most important aspects of the biological cycle of these animals (Muiño et al., 1999). There are, basically, two methods of studying this parameter: (1) through physiological analysis, which consists of the inspection of evidence directly related to reproduction (e.g. gonadal development: according to Costa \& Negreiros-Fransozo, 1998; Baptista-Metri et al., 2005); and (2) based on morphological data, which indicate the size at which the animal is able to copulate, considering the differential growth of certain structures (Abelló et al., 1990; Haefner, 1990; Araújo et al., 2011). However, the results of these different methods do not always agree, although both provide an accurate estimate of the beginning of maturity in these animals. In the present study, females became morphologically mature at smaller sizes than males, following the general pattern of portunids (see the review by Pinheiro \& Fransozo, 1998). This constitutes an important reproductive adaptation, considering that in the majority of the Portunidae, pair formation and copulation involve males in intermoult and females in recent post-moult, which need protection by the male during the post-copulatory embrace, until the hardening of their exoskeleton (Hartnoll, 1969; Christy, 1987; Pinheiro \& Fransozo, 1999).

\section{Fecundity}

In females of brachyurans, egg production is limited by the cephalothoracic cavity, where the gonads are located and yolk accumulates (Hines, 1982, 1992), and the size of the female is the principal determinant of fecundity (Hines, 1988). Nevertheless, external factors such as temperature, photoperiod, availability of food, salinity and the lunar cycle can determine the periodicity and length of the reproductive period (Colpo \& Negreiros-Fransozo, 2003). According to Sartor (1989), of 54,260 specimens of A. spinicarpus caught along the northern coast of São Paulo $\left(23^{\circ}\right.$ to $\left.24^{\circ} \mathrm{S}\right)$, ovigerous females occurred during the entire year, although in greater numbers in the warmer months. Therefore, A. spinicarpus can be assigned to the seasonal-continuous reproductive pattern proposed by Pinheiro \& Fransozo (2002). This pattern is characterized by the presence of females that are ovigerous and/or have mature gonads during all months of the year, but in uneven percentages, with greater intensity in certain months or seasons.

The fecundity of A. spinicarpus is relatively low because of its small body size and small size at sexual maturity, compared to other swimming crabs. The family Portunidae shows wide plasticity in the fecundity of the species (see review by Pinheiro \& Terceiro, 2000). Fecundity reaches a maximum of two million eggs in some members of Portunidae (e.g. Callinectes sapidus Rathbun, 1896, according to Van Engel, 1958); in contrast to the Polybiinae, which produce fewer eggs per spawning, even when individuals of identical size are compared. According to Pinheiro \& Terceiro (2000), this results from the animals of this subfamily reaching sexual maturity at a smaller size, in addition to the effect caused by latitudinal differences, which can affect egg production (Hartnoll \& Gould, 1988).

The distribution of the Polybiinae is concentrated in temperate regions, where environmental conditions, especially temperature, are more rigorous and limiting. However, although A. spinicarpus is a member of the Portunidae, it has relatively low fecundity, similar to that of the polybiine swimming crabs, which can be explained by tracking the movements of the SACW cold water mass (Pires, 1992). According to Hartnoll \& Gould (1988), the fecundity of decapod crustaceans showed a negative correlation with the latitude at which the species occur, being lower at higher latitudes as a function of limiting environmental factors, where temperature also tends to be lower and photoperiod shorter. Lardies \& Castilla (2001) corroborated this statement, recording a negative correlation between fecundity and size (or volume) of eggs as a function of latitude. Thus, at higher latitudes, larger eggs (with more yolk) are produced, generating larvae that are larger and potentially more likely to survive in the plankton (Schuh \& Diesel, 1995; Diesel \& Schuh, 1998; Brante et al., 2003, 2004). Other investigators, however, have attributed such differences among populations to different environmental (Bas et al., 2007) or genetic factors (Hancock et al., 1998), rather than to the latitudinal gradient.

Reid \& Corey (1991) compared the fecundity of 15 species of brachyurans and anomurans, including 20 specimens of 


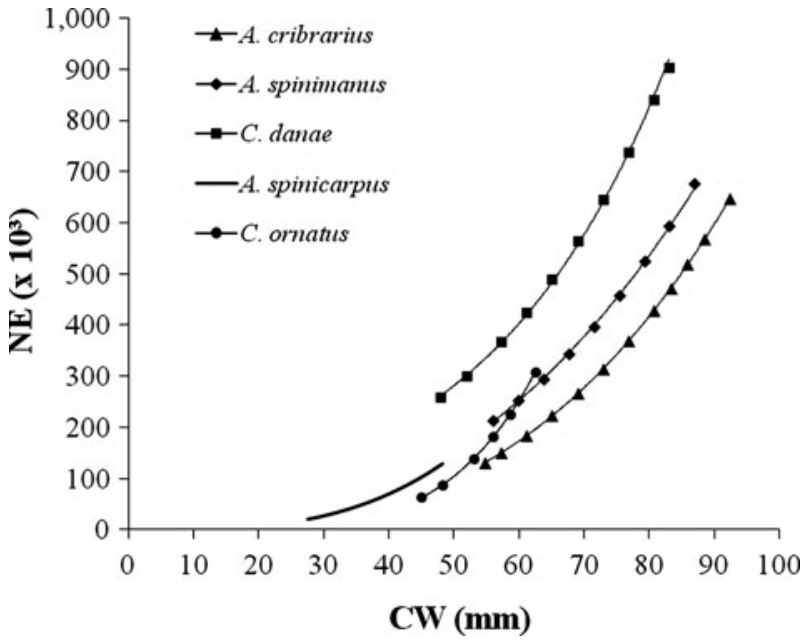

Fig. 4. Comparative analysis of the equations for potential fecundity of the regression $\mathrm{NE} \times \mathrm{CW}$ for the portunid crabs of the south-east continental shelf (NE, number of eggs; CW, carapace width without lateral spines). Arenaeus cribrarius, Pinheiro \& Terceiro (2000); Callinectes danae, Costa \& NegreirosFransozo (1996); Achelous spinimanus, Santos \& Negreiros-Fransozo (1998); Callinectes ornatus, Mantelatto \& Fransozo (1997); Achelous spinicarpus = present study.

A. spinicarpus obtained in the Gulf of Mexico. According to these investigators, the mean fecundity of this species was 32,204 eggs, much lower than that found in the present study (53,984 eggs). Possibly this occurred because of the small number of specimens analysed and the low variation in size ( 16.5 to $23.2 \mathrm{~mm} \mathrm{CL}$ ), which corresponds to 26.7 and $37.4 \mathrm{~mm} \mathrm{CW}$, according to inter-conversion by the equation obtained in the present study $\left(\mathrm{CL}=0.5834 \mathrm{CW}^{1.017}\right)$.

In spite of the low fecundity of A. spinicarpus, one of the smallest members of the family Portunidae, this species is mentioned as the most abundant in benthic samples from the western Atlantic (Sartor, 1989; Puentes et al., 1990; Pires, 1992). Figure 4 shows the potential fecundity of the principal swimming crabs that have been studied on the south-eastern continental shelf of Brazil. The variation in this parameter (e.g. five times greater in Arenaeus cribrarius and Achelous spinimanus (Latreille, 1819), and seven in Callinectes danae Smith, 1869) is related principally to the size reached by the females, which is much lower in A. spinicarpus than in the other species studied.

Hines (1992) mentioned the small energy investment of this species in egg production (3.2\%), as estimated based on the percentage of the egg mass in relation to the total weight of the female, which is $1 / 3$ of the mean value observed for other brachyurans (10\% according to Hines, 1982). Nevertheless, this portunid is one of the most abundant macroinvertebrates on unconsolidated marine bottoms, and is intimately associated with the frontal zone of the SACW, following its movements during the year. Sartor (1989) suggested that this distribution pattern favours A. spinicarpus, since the frontal system of this water mass could displace animals that are susceptible to low temperatures, making them easy prey for this carnivore.

This study is the first treatment of morphological and reproductive aspects of $A$. spinicarpus on the south-eastern continental shelf of Brazil. The data obtained corroborate those described in the literature for other portunids, emphasizing the peculiarity of the carpal spines as indicative of morphological sexual maturity for males, and the association of the species with the SACW, which possibly significantly influences its bioecology, as inferred for the fecundity. In spite of these results, further studies should be carried out in order to better understand the growth and reproduction of this species along the Brazilian coast.

\section{ACKNDWLEDGEMENTS}

FAPESP provided financial support to the first author for the conduct of this research (Proc. \#2009/11711-0). We thank CEPSUL/IBAMA for making it possible to use the RV 'Soloncy Moura' during the II Oceanographic Cruise of UNESP/CLP. We are also grateful to students R.R. Melo, W.P. Costa and V.S. Soares, and to Professor Dr B.S. Sant'Anna for their assistance with the laboratory procedures. Finally, we thank Dr Janet Reid (JWR Associates) who provided the editing of our English.

\section{REFERENCES}

Abelló P., Pertierra J.P. and Reid D.G. (1990) Sexual size dimorphism, relative growth and handedness in Liocarcinus depurator and Macropipus tuberculatus (Brachyura: Portunidae). Scientia Marina 54, 195-202.

Araújo M.S.L.C., Negromonte A.O., Barreto A.V. and Castiglioni D.S. (2011) Sexual maturity of the swimming crab Callinectes danae (Crustacea: Portunidae) at the Santa Cruz Channel, a tropical coastal environment. Journal of the Marine Biological Association of the United Kingdom 92, 287-293. DOI: 10.1017/Soo25315411001135.

Baptista-Metri C., Pinheiro M.A.A., Blankensteyn A. and Borzone C. (2005) Biologia populacional e reprodutiva de Callinectes danae Smith (Crustacea: Portunidae), no Balneário Shangri-lá, Pontal do Paraná, Paraná, Brasil. Revista Brasileira de Zoologia 22, 446-453.

Bas C.C., Spivak E.D. and Anger K. (2007) Seasonal and interpopulational variability in fecundity, egg size, and elemental composition $(\mathrm{CHN})$ of eggs and larvae in a grapsoid crab, Chasmagnathus granulatus. Helgoland Marine Research 61, 225-237.

Bertini G. and Fransozo A. (2004) Bathymetric distribution of brachyuran crab (Crustacea, Decapoda) communities on coastal soft bottoms off southeastern Brazil. Marine Ecology Progress Series 279, 193-200.

Bookhout C.G. and Costlow Jr J.D. (1974) Larval development of Portunus spinicarpus reared in the laboratory. Bulletin of Marine Science 24, 20-51.

Boolootian R.A., Giese A.C., Farmanfarmaian A. and Tucker J. (1959) Reproductive cycles of five west coast crabs. Physiological Zoology 32, 213-220.

Braga A.A., Fransozo A., Bertini G. and Fumis P.B. (2005) Composição e abundância de caranguejos (Decapoda, Brachyura) nas regiões de Ubatuba e Caraguatatuba, litoral norte paulista, Brasil. Biota Neotropica 5, 1-34.

Brante A., Cifuentes S., Pörtner H.O., Arntz W. and Fernández M. (2004) Latitudinal comparisons of reproductive traits in five brachyuran species along the Chilean coast. Revista Chilena de Historia Natural 77, 15-27.

Brante A., Fernández M., Eckerle L., Mark F., Pörtner H.O. and Arntz W. (2003) Reproductive investment in the crab Cancer setosus along a latitudinal cline: egg production, embryo losses and embryo ventilation. Marine Ecology Progress Series 251, 221-232. 
Christy J.H. (1987) Competitive mating, mate choice and mating associations of brachyuran crabs. Bulletin of Marine Science 41, 177-191.

Colpo K.D. and Negreiros-Fransozo M.L. (2003) Reproductive output of Uca vocator (Herbst, 1804) (Brachyura, Ocypodidae) from three subtropical mangroves in Brazil. Crustaceana 76, 1-11.

Costa T.M. and Negreiros-Fransozo M.L. (1996) Fecundidade de Callinectes danae Smith, 1869 (Crustacea, Decapoda, Portunidae) na região de Ubatuba (SP), Brasil. Arquivos de Biologia e Tecnologia 39 393-400.

Costa T.M. and Negreiros-Fransozo M.L. (1998) The reproductive cycle of Callinectes danae Smith, 1869 (Decapoda, Portunidae) in the Ubatuba region, Brazil. Crustaceana 71, 615-627.

De Léo F.C. and Pires-Vanin M.S. (2006) Benthic megafauna communities under the influence of the South Atlantic Central Water intrusion onto the Brazilian SE shelf: a comparison between an upwelling and a non-upwelling ecosystem. Journal of Marine Systems 60, 268 284.

Diesel R. and Schuh M. (1998) Effects of salinity and starvation on larva development of the crabs Armases ricordi and A. roberti (Decapoda: Grapsidae) from Jamaica, with notes on the biology and ecology of adults. Journal of Crustacean Biology 18, 423-436.

FAO-GLOBEFISH (2007) Crab commodity update. Copenhagen: GLOBEFISH databank, $28 \mathrm{pp}$.

Flores A. and Negreiros-Fransozo M.L. (1999) Allometry of the secondary sexual characters of the shore crab Pachygrapsus transversus (Gibbes, 1850) (Brachyura, Grapsidae). Crustaceana 72, 1051-1066.

Freire A.S., Pinheiro M.A.A., Karam-Silva H. and Teschima M.M. (2011) Biology of Grapsus grapsus (Linnaeus, 1758) (Brachyura, Grapsidae) in the Saint Peter and Saint Paul Archipelago, Equatorial Atlantic Ocean. Helgoland Marine Research 65, 263-273.

García-Montes J.F., Soto L.A. and Gracia A. (1988) Cangrejos portúnidos del suroeste del Golfo de México. Aspectos pesqueros y ecológicos. Anales del Instituto de Ciencias del Mar y Limnología, Universidad Nacional Autónoma de México 15, 135-150.

Haefner Jr P.A. (1985) The biology and exploration of crabs. In Provenzano Jr A.J. (ed.) The biology of Crustacea: economic aspects: fisheries and culture. New York: Academic Press, pp. 111-116.

Haefner Jr P.A. (1990) Morphometric growth and size at maturity of Callinectes ornatus (Brachyura: Portunidae) in Bermuda. Bulletin of Marine Science 46, 274-286.

Hancock M., Hughes J. and Bunn S. (1998) Influence of genetic and environmental factors on egg and clutch sizes among populations of Paratya australiensis Kemp (Decapoda: Atyidae) in upland rain-forest streams, south-east Queensland. Oecologia 115, 483-491.

Hartnoll R.G. (1965) Notes on the marine grapsid crabs of Jamaica. Proceedings of the Linnean Society of London 176, 113-147.

Hartnoll R.G. (1969) Mating in the Brachyura. Crustaceana 16, 161-181.

Hartnoll R.G. (1974) Variation in growth pattern between some second ary sexual characters in crabs (Decapoda, Brachyura). Crustaceana 27, $131-136$.

Hartnoll R.G. (1978) The determination of relative growth in Crustacea. Crustaceana 34, 281-293.

Hartnoll R.G. (1985) Growth, sexual maturity and reproductive output. In Wenner A.M. (ed.) Crustacean Issues, 3: factors in adult growth Rotterdam: A.A. Balkema, pp. 101-128.

Hartnoll R.G. and Gould P. (1988) Brachyuran life history strategies and the optimization of egg production. In Fincham A.A. and Rainbow P.S (eds) Aspects of decapod crustacean biology. Oxford: Clarendon Press, pp. 1-9.
Hattori G.Y., Sant'Anna B.S. and Pinheiro M.A.A. (2006) Meat yield of Callinectes bocourti A. Milne Edwards, 1879 (Crustacea, Portunidae) in Iguape, São Paulo, Brazil. Investigaciones Marinas 34, 231-236.

Hines A.H. (1982) Allometric constraints and variables of reproductive effort in brachyuran crabs. Marine Biology 69, 309-320.

Hines A.H. (1988) Fecundity and reproductive output in two species of deep-sea crabs, Geryon fenneri and G. quinquedens (Decapoda: Brachyura). Journal of Crustacean Biology 8, 557-562.

Hines A.H. (1992) Constraint on reproductive output in brachyuran crabs: pinnotherids test the rule. American Zoologist 32, 503-511.

Holthuis L.B. (1969) Portunus binoculus, n. sp., a new deep-water swimming crab from the Caribbean region (Crustacea, Decapoda, Brachyura). Bulletin of Marine Science 19, 409-427.

Huxley J.S. (1950) Relative growth and form transformation. Proceedings of the Zoological Society of London B 137, 465-469.

Jivoff P. and Hines A. (1998) Female behaviour, sexual competition and mate guarding in the blue crab, Callinectes sapidus. Animal Behaviour $55,589-603$.

Lardies M.A. and Castilla J.C. (2001) Latitudinal variation in the reproductive biology of the commensal crab Pinnaxodes chilensis (Decapoda: Pinnotheridae) along the Chilean coast. Marine Biology 139, $1125-1133$.

Mantelatto F.L.M. and Fransozo A. (1997) Fecundity of the crab Callinectes ornatus Ordway, 1863 (Decapoda, Brachyura, Portunidae) from the Ubatuba region, São Paulo, Brazil. Crustaceana 70, 214-226.

Mantelatto F.L.M., Robles R. and Felder D.L. (2007) Molecular phylogeny of the western Atlantic species of the genus Portunus (Crustacea, Brachyura, Portunidae). Zoological Journal of the Linnean Society 150, 211-220.

Mantelatto F.L.M., Robles R., Schubart C.D. and Felder D.L. (2009) Molecular phylogeny of the genus Cronius Stimpson, 1860, with reassignment of C. tumidulus and several American species of Portunus to the genus Achelous De Haan, 1833 (Brachyura: Portunidae). In Martin J.W., Crandall K.A. and Felder D.L. (eds) Crustacean Issues 18: decapod crustacean phylogenetics. Boca Raton, FL: Taylor and Francis/CRC Press, pp. 567-579.

Melo G.A.S. (1996) Manual de Identificação dos Brachyura (Caranguejos e Siris) do Litoral Brasileiro. São Paulo, SP: Ed. Plêiade/FAPESP, 604 pp.

Morgan S.G. (1987) Morphological and behavioral antipredatory adaptations of decapod zoeae. Oecologia 73, 393-400.

Muggeo V.M.R. (2008) Segmented: an R package to fit regression models with broken-line relationships. $R$ News 8, 20-25.

Muiño R., Fernández L., González-Gurriáran E., Freire J. and Vilar J.A. (1999) Size at maturity of Liocarcinus depurator (Brachyura: Portunidae): a reproductive and morphometric study. Journal of the Marine Biological Association of the United Kingdom 79, 295-303.

Pinheiro M.A.A. and Fransozo A. (1993) Relative growth of the speckled swimming crab Arenaeus cribrarius (Lamarck, 1818) (Brachyura, Portunidae), near Ubatuba, State of São Paulo, Brazil. Crustaceana $65,365-376$.

Pinheiro M.A.A. and Fransozo A. (1998) Sexual maturity of the speckled swimming crab Arenaeus cribrarius (Lamarck, 1818) (Decapoda, Brachyura, Portunidae) in the Ubatuba littoral, São Paulo State, Brazil. Crustaceana 71, 434-452.

Pinheiro M.A.A. and Fransozo A. (1999) Reproductive behavior of the swimming crab Arenaeus cribrarius (Lamarck, 1818) (Crustacea, Brachyura, Portunidae) in captivity. Bulletin of Marine Science 64, 243-253. 
Pinheiro M.A.A. and Fransozo A. (2002) Reproduction of the speckled swimming crab Arenaeus cribrarius (Brachyura: Portunidae) on the Brazilian coast near $23^{\circ} 30^{\prime}$ S. Journal of Crustacean Biology 22, 416-428.

Pinheiro M.A.A. and Hattori G.Y. (2006) Relative growth of the mangrove crab Ucides cordatus (Linnaeus, 1763) (Crustacea, Brachyura, Ocypodidae) at Iguape, São Paulo, Brazil. Brazilian Archives of Biology and Technology 49, 813-823.

Pinheiro M.A.A. and Terceiro O.S.L. (2000) Fecundity and reproductive output of the speckled swimming crab Arenaeus cribrarius (Lamarck, 1818) (Brachyura, Portunidae). Crustaceana 73, 1121-1137.

Pires A.M.S. (1992) Structure and dynamics of benthic megafauna on the continental-shelf offshore of Ubatuba, southeastern Brazil. Marine Ecology Progress Series 86, 63-76.

Puentes L.G., Campos N.H. and Reyes R. (1990) Decápodos de fondos blandos hallados en el área comprendida entre Pozos Colorados y la Bahía de Taganga, Caribe colombiano. Boletín Ecotrópica 23, 31-41.

R Development Core Team (2011) R: a language and environment for statistical computing. Vienna, Austria: R Foundation for Statistical Computing. ISBN 3-900051-07-0, URL http://www.R-project.org/

Rasheed S. and Mustaquim J. (2010) Size at sexual maturity, breeding season and fecundity of three-spot swimming crab Portunus sanguinolentus (Herbst, 1783) (Decapoda, Brachyura, Portunidae) occurring in the coastal waters of Karachi, Pakistan. Fisheries Research 103, 56-62.

Reid D.M. and Corey S. (1991) Comparative fecundity of decapod crustaceans, II. the fecundity of fifteen species of anomuran and brachyuran crabs. Crustaceana 61, 175-189.

Santos S. and Negreiros-Fransozo M.L. (1998) Fecundity in Portunus spinimanus Latreille, 1819 (Crustacea, Brachyura, Portunidae) from Ubatuba, São Paulo, Brazil. Interciencia 22, 259-263.

Sanvicente-Anõrve L., Gómez-Ponce A., Vázquez-Bader A.R. and Gracia A. (2008) Morphometry and relative growth of the swimming crab, Portunus spinicarpus (Stimpson, 1871) from the southern Gulf of Mexico. Crustaceana 81, 329-339.

Sartor S.M. (1989) Composição e distribuição dos Brachyura (Crustacea, Decapoda), no litoral norte do Estado de São Paulo. PhD thesis. Universidade de São Paulo, São Paulo, Brazil.
Sastry A.N. (1983) Ecological aspects of reproduction. In Vernberg F.J. and Vernberg W.D. (eds) The biology of Crustacea: environmental adaptations. New York: Academic Press, pp. 179-270.

Schuh M. and Diesel R. (1995) Effects of salinity, temperature, and starvation on the larval development of Armases (= Sesarma) miersii (Rathbun, 1897), a semiterrestrial crab with abbreviated development (Decapoda: Grapsidae). Journal of Crustacean Biology 15, 205-213.

Severino-Rodrigues E., Guerra D.S.F. and Graça-Lopes R. (2002) Carcinofauna acompanhante da pesca dirigida ao camarão-sete-barbas (Xiphopenaeus kroyeri) desembarcada na praia do Perequê, Estado de São Paulo, Brasil. Boletim do Instituto de Pesca 28, 33-48.

Severino-Rodrigues E., Hebling N.J. and Graça-Lopes R. (2007) Biodiversidade no produto da pesca de arrasto-de-fundo dirigida ao lagostim, Metanephrops rubellus (Moreira, 1903), desembarcado no litoral do estado de São Paulo, Brasil. Boletim do Instituto de Pesca $33,171-182$.

Van Engel W.A. (1958) The blue crab and its fishery in Chesapeake Bay. Part 1-reproduction, early development, growth and migration. Commercial Fisheries Review 20, 6-17.

Williams A.B. (1984) Shrimps, lobsters and crabs of the Atlantic coast of the eastern United States, Maine to Florida. Washington, DC: Smithsonian Institution Press, 550 pp.

and

Zar J.H. (1996) Biostatistical analysis. 3rd edition. Upper Saddle River, NJ: Prentice-Hall, 662 pp.

\section{Correspondence should be addressed to:}

M.A.A. Pinheiro

Praça Infante Dom Henrique

s/no-Pq. Bitam

CEP 11.330-900

São Vicente (SP), Brazil

email: pinheiro@clp.unesp.br 